\title{
Plant species composition and potential feed value of permanent grasslands in the Sýkořská hornatina Upland
}

\author{
*Pavel Nerušil ${ }^{1}$, Petr Komárek², Zuzana Křivánkováa ${ }^{1}$ Ladislav Menšík ${ }^{1}$ \\ ${ }^{1}$ Department of Sustainable Management and Utilization of Permanent Grassland, Grassland Research Station \\ Jevícko, Crop Research Institute, Prague-Ruzyně, K. H. Borovského 461, 56943 Jevićko, Czech Republic, E-mail: \\ nerusil@vurv.cz, ladislav.mensik@vurv.cz \\ ${ }^{2}$ Jevíćská 293, 67963 Velké Opatovice
}

\begin{abstract}
Nerušil P., Komárek P., KřivánkováZ., Menšík L., 2017: Plant species composition and potential feed value of permanent grasslands in the Sýkořská hornatina Upland. - Beskydy, $10(1,2): 135-144$
\end{abstract}

In multifunctional agriculture, permanent grasslands (PG) present an important culture which keeps the soil in the continuous production status while helping to shape the landscape and protecting biodiversity, plus it has a number of other non-productive functions. The aim of the study was to evaluate, using the "Inventory and Classification of PG" method, species composition and the feed value of fodder in permanent grasslands in a specific farming company (ZEAS Lysice, a. s.) located in the area of the Sýkořská hornatina Upland. Multivariate analysis of PCA identified three categories of sites in the area: (1) PG with a low proportion of grass species and a high proportion of other herbs (47-55\%); (2) PG with a high proportion of grass species (68-81\%); (3) PG with a mediumhigh proportion of grass species (50-60\%), legumes (1 \%) and other herbs. Most of PG are completely lacking legumes which supply nitrogen to the vegetation and are a major improvement for fodder production and its quality. Additional seeding of grass-clover mixtures seems to be a useful way to improve the botanical composition of meadows and pastures in the area of interest.

Key words: grassland; plant species composition; feed value; PCA analysis; Sýkořská hornatina Upland; Czech Republic.

\section{Introduction}

Permanent grasslands (PG) are characterized as a mixed perennial plant communities involving grasses (dominant), clovers (legumes) and other herbs (dicotyledonous species) which are formed by site conditions and human activity (Rychnovská 1985, Novák 2008). Hrabě (2003) points out that permanent grasslands (PG) are the only cultures capable of temporarily replacing the irreplaceable function of forest, in terms of permanent stability of the landscape and living conditions, as they have a number of characteristics consistent with forest ecosystems.
In the Czech Republic, PG occupy an area of about 1,003 thousand ha, which is $24 \%$ of the total agricultural land, i.e., 4,215,000 ha (MoA 2015). The major portion of the PG area is found in less-favoured areas (LFA). The productive importance of PG lies in the fact that they present an important source of bulky, carbohydrateprotein feedstuff for livestock, especially in LFA (Rychnovská et al. 1985; Štýbnarová 2011), as well as a substrate for biogas plants (BGP) as a substitute for maize (Nerušil et al. 2016). Based on site conditions and the management system, 
yields range from 1.6 and $8.0 \mathrm{t}$ of hay per ha; in renewed grasslands or those where additional seeding was applied, the yield can reach 10-12 t of quality hay per hectare (Pozdíšek et al. 2004).

Botanical composition is crucial for ensuring productive and non-productive functions of PG (Michaud et al. 2012), including the quality parameters of produced fodder; fodder quality is based on high digestibility, nutrient concentration and nutrient ratio (Gaujour et al. 2012; da Silveira Pontes et al. 2015). In the long term, botanical composition/fodder quality can be influenced by fertilising and crop utilisation systems, i.e., the intensity and frequency of grazing, alternating mowing and grazing or numbers of cuts during the year (Hejcman et al. 2007, 2010; Nerušil et al. 2012).

The aim of the study was to evaluate, using the "Inventory and Classification of PG" method, species composition and the feed value of fodder in permanent grasslands in a specific farming company located in the area of the Sýkořská hornatina Upland.

\section{Material and methods}

\section{Site description:}

Permanent grasslands (PG) found on the land of ZEAS Lysice, a. s., a farming company, were subjected to the studies in 2001-2002 (Fig 1); the plots were found in the territory of the Sýkořská hornatina Upland approximately $30 \mathrm{~km}$ north of the city of Brno, Czech Republic. In geomorphologic point of view, the area of interest belongs into Hornosvratecká vrchovina Upland unit, Nedvědická vrchovina Upland subunit and Sýkořská hornatina Upland district $\left(214.24 \mathrm{~km}^{2}\right)$. A more comprehensive description of grassland stands is given in Table 1. Geological bedrock the area of interest consists of Moravika rocks - orthogneisses, paragneisses, siltstones and sandstones (Hanžl, Buriánková 2000).

The farming company manages a farm land of 2,077 hectares found at an elevation of 320 to $668 \mathrm{~m}$. The mean annual air temperature is $7.5^{\circ} \mathrm{C}$ and annual average yearly rainfall is $618 \mathrm{~mm}$ (observational weather station in Lysice, $365 \mathrm{~m}$ a.s.l.). The company cultivates cereals, rape seed, maize for silage, other annual fodder crops (alfalfa, red clover, and clover-grass mixtures). Permanent grasslands (419 ha) represent $20.1 \%$ of the farm land. The company is focused on raising cattle (1,928 individuals, of which 376 are dairy cows), pigs (500) and chicken broilers $(50,000)$. Farm land load by herbivores equals 0.57 livestock units per hectare. Soil types beneath PG involve Cambisols and Gleysols (Němeček et al. 2011; WRB 2014).

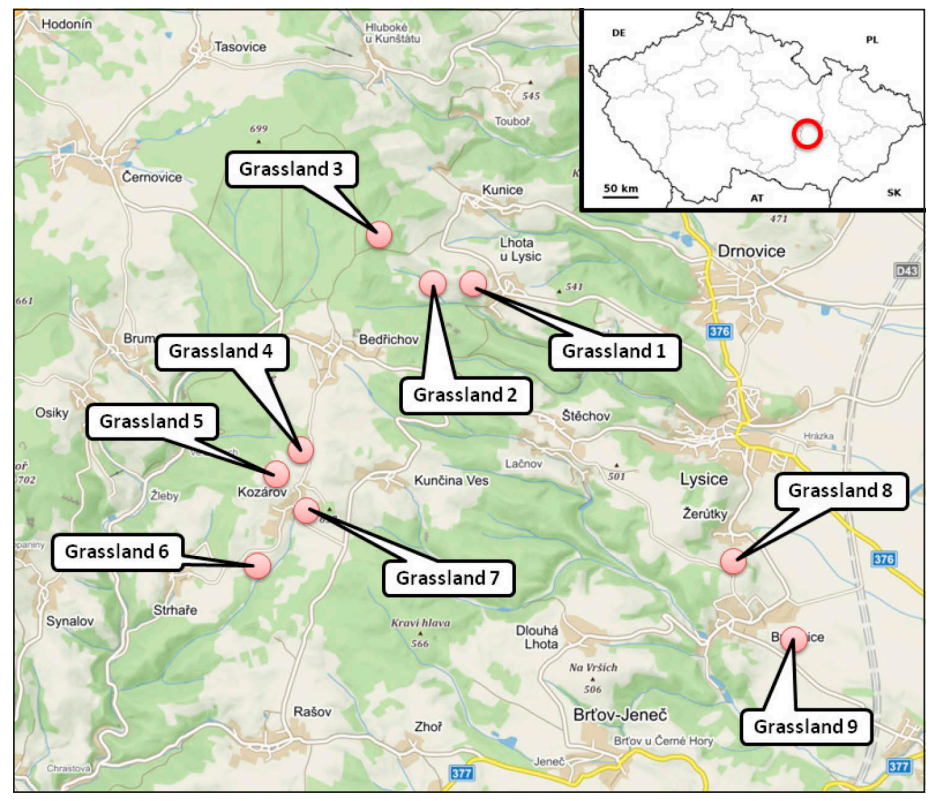

Fig. 1: A map giving an overview of the area indicating the monitored PG (base data sourced from www.seznam.cz). 


\section{Methods:}

The representation of individual plant species primary agrobotanical groups and gaps of the PG observed was carried out by the method of reduced projective dominance - visual assessment of the stand (Horký et al. 2013). The phytocoenological pictures were performed two-times in reference area sized $10 \mathrm{~m}^{2}$ and recorded as \% of coverage (D \%) and using the Braun-Blanquet scale $(+=$ coverage of $0.33 \%$, $\mathrm{r}$ - individual plants in the stand). The nomenclature of plants follows the botanical dictionary by Kubát et al. (2002). The potential value of the fodder was evaluated by a number of quality (WZ-Wertzahl) according to Klapp (1956), where 8 = the highest-quality fodder, -1 = toxic species; the total calculated value was increased by gaps. The overall evaluation of each PG was carried out by the "PG Inventory and Classification" method according to Koníček et al. 1966).

\section{Statistical analysis:}

Statistical analysis, including graphical outputs, were carried out using STATISTICA 12.0 (Stat-Soft Inc., Tulsa USA, StatSoft ČR, s. r. o. 2014). Principal Component Analysis (PCA) was used for interpreting of the agrobotanical groups (Graminoids, Legumes, Forbs) and the gaps. Selected measured characteristics were used as predictors (factors); they were chosen on the basis of an eigenvalue graph. Variables with impaired assumption of normality were converted using logarithmic transformation. PCA was used for calculating a component weight for the investigated variables (Meloun, Militký 2011). Based on correlations and contributions in convincing factors each of the characteristics was subsequently judged for relevance to explain the multidimensional dependencies (correlations) in the factorial plane. Statistical significance was assessed at a significance level of $\mathrm{P}=0.05$ (Meloun, Militký 2012).

\section{Results}

The representation of plant species in permanent grasslands (PG) is very diverse. The number of species was identified to be 5 to 9 at individual sites (PG) with with Dactylis glomerata (L.), Poa pratensis (L.), Arrhenantherum elatius (L.) and Alopecurus pratensis (L.) being the grasses represented to the greatest extent. Of legumes, this involved only Trifolium repens (L.); of herbs, Taraxacum sect. ruderalia, Anthriscus sylvestris (L.), Rumex acetosa (L.) and Rumex obtusifolius (L.) featured the highest percentage; for other species, refer to Appendix A. Supplementary data.

For the summary characteristic of primary agrobotanical groups and gaps see Table 2. In each of the PG, grass presence is $30 \%$ to $81 \%$. At two sites (PG4 and 6) there was 1\% legumes. At four sites (PGI, 3, 4 and 5) herbs prevailed over grasses and legumes. Gaps were evaluated to range from $1 \%$ to $20 \%$. Potential feed value of fodder was found to range from $493 \mathrm{WZ}$ to 676 WZ. The lowest potential quality was found at PG 1-6, while the highest quality was seen at PG 7-9 with higher presence of grasses (Table 2).

On the chart of component weights $\mathrm{PCl}$ and PC2 there are only the first two axes significant, which together explain about $91 \%$ of the variability (Fig 2). Axis PCl clearly characterises the representation of grasses, other herbs, empty spaces and potential feed value that go straight along that axis and are correlated with it over 0.8-0. 9. Axis PC2 shows no strong correlation; the direction is however discerned based on the representation of legumes in PG. Multivariate analysis PCA (axes PCl and PC2) significantly discerned, in the evaluated parameters - see Graminoids, Legumes, Forbs, Gaps and Potential feed value - three categories of PG sites: (1) PG 1, 3, 5 - low representation of grass species (30\% to $42 \%$ ), high representation of other herbs; (2) PG2, 7, 8, 9 - high representation of grass species (68\% to $81 \%$ ), very low representation of other herbs; (3) PG 4, 6 - medium-high representation of grass species ( $50 \%$ to $60 \%$ ), representation of legumes (1 \%) and other herbs (39\% to $47 \%$ ). 


\begin{tabular}{|c|c|c|c|c|c|c|c|c|c|c|c|c|c|c|c|c|}
\hline $\begin{array}{l}\hat{U} \\
\mathrm{a}\end{array}$ & 욤 & 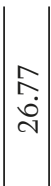 & 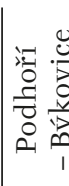 & $a_{1}$ & $\begin{array}{l}z_{1} \\
m\end{array}$ & L & & $\begin{array}{l}\overline{0} \\
.0 \\
0 \\
\text { है } \\
0 \\
0\end{array}$ & Z & $\infty$ & 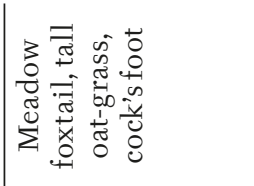 & $\odot$ & $\stackrel{n}{m}$ & $\frac{2}{4}$ & $\begin{array}{l}\infty \\
\sum\end{array}$ & 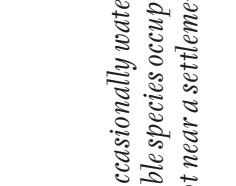 \\
\hline $\mid$\begin{tabular}{l}
$\infty$ \\
$\vdots$ \\
\hdashline \\
\hdashline
\end{tabular} & $\begin{array}{l}0 \\
\tilde{\gamma}\end{array}$ & $\mid \begin{array}{l}8 \\
0 \\
0 \\
0\end{array}$ & 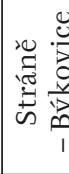 & $\Sigma$ & $\hat{m}$ & 山 & & $\begin{array}{l}\overline{0} \\
.0 \\
0 \\
\text { है } \\
0 \\
0\end{array}$ & Z & $\infty$ & 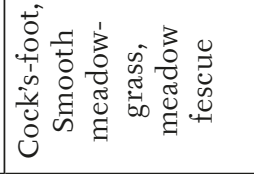 & $\odot$ & $\stackrel{\circ}{\stackrel{+}{*}}$ & $\frac{\pi}{4}$ & i & 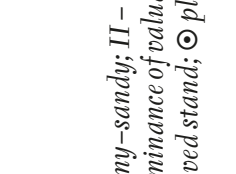 \\
\hline ज̂ & 옹 & $\left|\begin{array}{l}\hat{L} \\
\dot{m}\end{array}\right|$ & 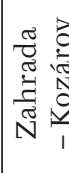 & $\Sigma$ & 3 & $\mathrm{H}$ & & 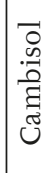 & $\exists$ & $\infty$ & 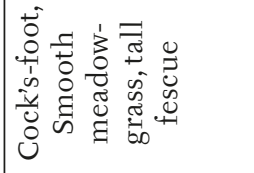 & $\odot$ & $\stackrel{\circ}{\stackrel{+}{*}}$ & 胥 & $\begin{array}{l}\text { \& } \\
\sum\end{array}$ & 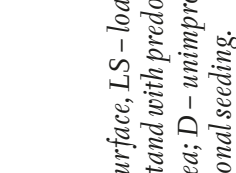 \\
\hline $\begin{array}{l}\stackrel{0}{0} \\
0\end{array}$ & ㅇํํ & 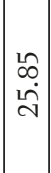 & 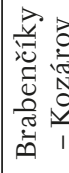 & ar & $\begin{array}{l}\omega \\
n\end{array}$ & L & & 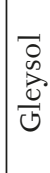 & $\exists$ & $\infty$ & 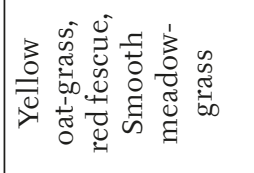 & $\odot$ & $\stackrel{n}{m}$ & $\frac{\pi}{4}$ & $\begin{array}{l}\infty \\
\sum \\
\Sigma \\
\Sigma\end{array}$ & 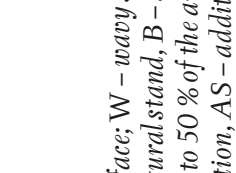 \\
\hline $\begin{array}{l}1 \\
\mathrm{~s} \\
\mathrm{a}\end{array}$ & $\begin{array}{l}0 \\
\hat{n}\end{array}$ & $\mid \begin{array}{l}\vec{f} \\
\dot{0}\end{array}$ & 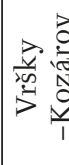 & $\Sigma$ & $\begin{array}{l}\infty \\
\infty \\
\infty\end{array}$ & H & 9 & $\begin{array}{l}\text { D } \\
.0 \\
.0 \\
\text { है } \\
0 \\
0\end{array}$ & Z & ن́ & 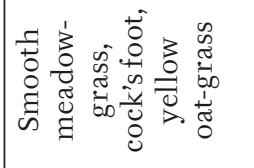 & $\odot$ & $\stackrel{\circ}{m}$ & $\frac{\pi}{4}$ & $\begin{array}{l}\infty \\
\sum\end{array}$ & 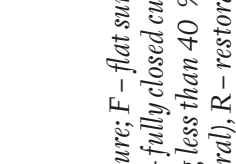 \\
\hline $\begin{array}{l}\vec{J} \\
0\end{array}$ & 농 & $\stackrel{\substack{f \\
-i}}{-}$ & $\mid \begin{array}{ll}2 & 0 \\
2 & 0 \\
z & 0 \\
0 & 0 \\
0 & 0 \\
0 & 1\end{array}$ & $\Sigma$ & $\begin{array}{l}z \\
n\end{array}$ & H & & $\begin{array}{l}0 \\
0 \\
.0 \\
0 \\
\tilde{c} \\
\tilde{\omega}\end{array}$ & Z & $u$ & 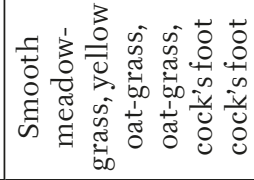 & $\odot$ & $\stackrel{\circ}{m}$ & $\frac{\pi}{4}$ & $\begin{array}{l}\infty \\
\sum \\
\Sigma \\
\sum\end{array}$ & 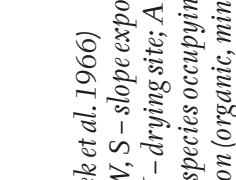 \\
\hline $\begin{array}{l}\hat{U} \\
\hat{G}\end{array}$ & $\hat{\tilde{r}}$ & 尽 & 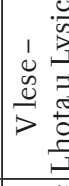 & $\Sigma$ & $\begin{array}{l}\infty \\
n\end{array}$ & L & & 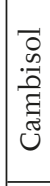 & $\geq$ & $u$ & 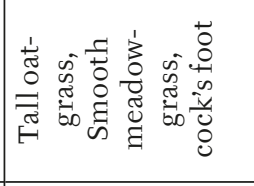 & $\odot$ & $\stackrel{i}{i}$ & $\frac{\pi}{4}$ & $\begin{array}{l}0 \\
\sum \\
\text { si } \\
\text { si }\end{array}$ & 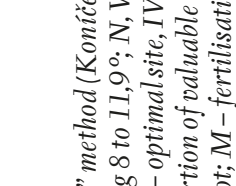 \\
\hline ળิ & $\begin{array}{l}0 \\
\infty \\
i n\end{array}$ & \begin{tabular}{|l} 
Ln \\
in
\end{tabular} & 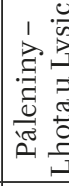 & $\Sigma$ & $\begin{array}{c}\infty \\
\infty \\
\infty\end{array}$ & 3 & & $\begin{array}{l}\text { D } \\
.0 \\
\text { है } \\
\text { है }\end{array}$ & Z & $\infty$ & 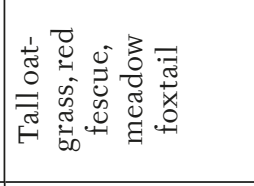 & $\odot$ & $\stackrel{n}{i}$ & 胥 & $\sum_{i}^{\infty}$ & 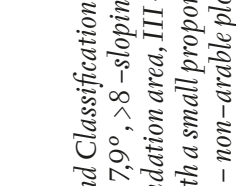 \\
\hline $\overrightarrow{\mathbb{G}}$ & : & $\vec{r}$ & 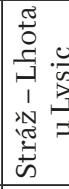 & $\Sigma$ & $\begin{array}{l}z \\
n\end{array}$ & H & & $\begin{array}{l}0 \\
.0 \\
\text { है } \\
0 \\
0\end{array}$ & Z & $\infty$ & 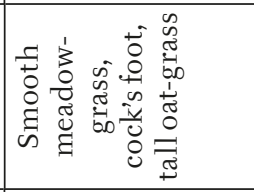 & $\odot$ & $\stackrel{n}{m}$ & $\frac{\pi}{4}$ & $\sum_{i}^{\infty}$ & 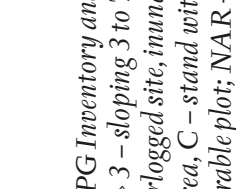 \\
\hline 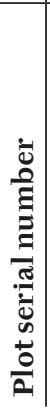 & 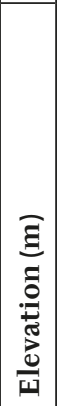 & 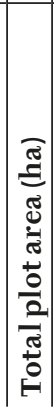 & 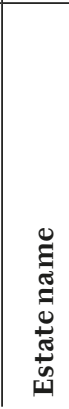 & 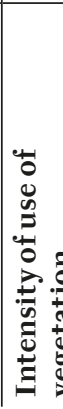 & 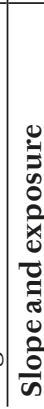 & 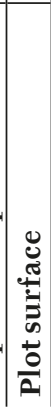 & 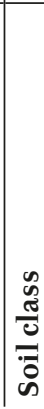 & 章 & 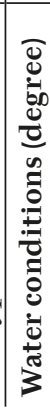 & 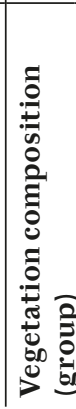 & 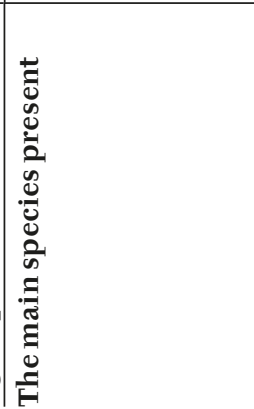 & 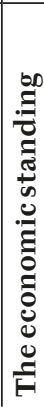 & 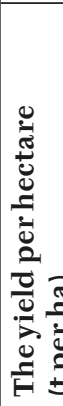 & 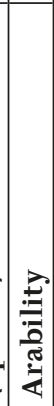 & 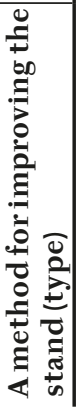 & 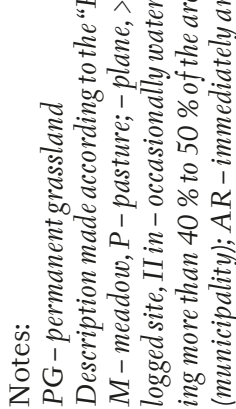 \\
\hline
\end{tabular}


Tab. 2: Overall characteristics of agrobotanical groups (Graminoids, Legumes, Forbs), the gaps and potential forage quality (WZ) of permanent grasslands.

\begin{tabular}{c|c|c|c|c|c|c}
\hline PG & Name of field & Graminoids (\%) & Legumes (\%) & Forbs (\%) & Gaps (\%) & WZ \\
\hline PG1 & Stráž & 42 & 0 & 48 & 10 & 550 \\
PG2 & Páleniny & 81 & 0 & 14 & 5 & 569 \\
PG3 & V lese & 35 & 0 & 55 & 10 & 541 \\
PG4 & Pod niví & 42 & 1 & 47 & 10 & 516 \\
PG5 & Vršky-Kozárov & 30 & 0 & 50 & 20 & 493 \\
PG6 & Brabenčíky & 50 & 1 & 39 & 10 & 524 \\
PG7 & Zahrada & 68 & 0 & 27 & 5 & 623 \\
PG8 & Stráně-Býkovice & 78 & 0 & 20 & 2 & 676 \\
PG9 & Podhoří & 70 & 0 & 29 & 1 & 637 \\
\hline
\end{tabular}

Notes: PG - permanent grassland; WZ - Wertzahl according to Klapp (1956)
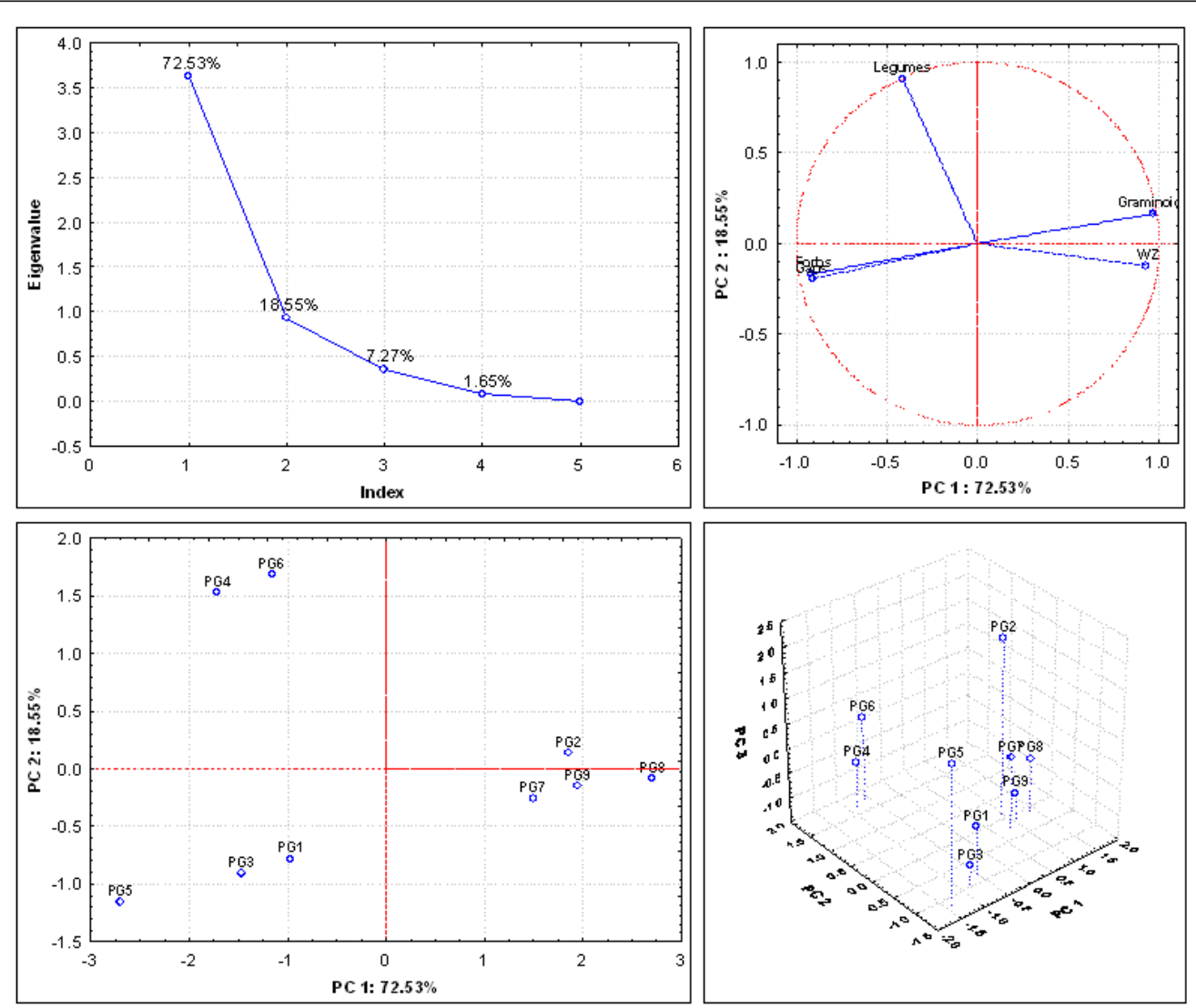

Fig. 2: PCA of agrobotanical groups (Graminoids, Legumes, Forbs), the gaps of permanent grasslands. 


\section{Discussion}

The farmed PG provide agronomic as well as environmental and ecological benefits. All of the above are influenced by farming and soil \& climatic factors (Michaud et al. 2012). In the study area, PG represent a source of a bulky, carbohydrate-protein feedstuff for milk and meat production; it conforms to the prevailing intensity of use of the grasslands (two PG classified as P-pastures, seven PG ranked as PG M-meadows) -Table 1. On most studied sites there were species of grass (Poa pratensis /L./; Dactylis glomerata /L./) with a high feed value of fodder (Klapp 1956). The rated PG also comprise a low (below 1 \%) representation of legumes (Trifolium repens /L./) that significantly increase fodder quality (Givens et al. 2000; Steinwidder, Wurm 2003, Nerušil et al. 2012) as well as species diversity (Pozdíšek et al. 2004; Štýbnarová 2011). Some sites (PG 1, 3, 5) are at varying stages of degradation (the representation of legumes being $0 \%$ and that of other herbs, i.e. Taraxacum sect. ruderalia, and even Rumex acetosa /L./ and Rumex obtusifolius /L./ etc., being high - see Appendix A. Supplementary data); while dry matter yields ranging between 2.5 to 4.0 tons per ha correspond with this situation (Table 1). Prospectively, the quality of stands will need to be enhanced by additional seeding (using clover-grass mixtures sown by a strip or harrow seeder) (Kohoutek et al. 2007) similarly to PG in Drahanská vrchovina Upland (Nerušil et al. 2016). In this direction, using a wide range of fodder crops will be critical in future /red clover, alfalfa/ (Hejduk 2012; Carter, Blair 2013; Walden, Lindborg 2016) that would be capable of reaching the required changes in quality over a short period (Gaujour et al. 2012; da Silveira Pontes et al. 2015).

\section{Conclusion}

In the Czech Republic, PG are now seen more as a means to perform a range of non-productive functions and, less frequently, as a source of cheap and natural fodder for livestock. Based on the research and a comprehensive review of PG on the land of ZEAS Lysice, a. s., a farming company, in the region of the Sýkořská hornatina Upland, conclusions can be drawn as follows:
- Mostly represented grass species comprised Dactylis glomerata (L.), Poa pratensis (L.), Arrhenantherum elatius (L.) and Alopecurus pratensis (L.); of legumes, Trifolium repens $\mathrm{L}$ was only present. Of other herbs, the there was the highest percentage of Taraxacum sect. ruderalia.

- Multivariate analysis PCA significantly discerned three categories of sites (PG) in the territory - (1) PG with a low proportion of grass species and a high proportion of other herbs (47\% to $55 \%$ ); (2) PG with a high proportion of grass species (68\% to $81 \%$ ); (3) PG with a medium-high proportion of grass species ( $50 \%$ to $60 \%$ ), proportion of legumes (1\%) and other herbs.

- Legumes that provide nitrogen supply to vegetation and significantly improve the fodder quality and production are completely missing in PG. At such sites, additional seeding by clover-grass mixtures, whether by means of a strip seeder or a harrow seeder, seems to be an appropriate way for improvement.

Useful pratotechnology measures can be applied to enhance the quality of grasslands for farming purposes; they include plant nutrition and fertilisation, additional seeding by sowing legumes into the initial grassland, timely cuts, as well as grazing by polygastric herbivores.

\section{Acknowledgements}

The study was prepared under the financial support of the project MZE RO0417 "Sustainable Systems and Technologies, Improving Crop Production for Higher Quality of Production of Food, Feed, and Raw Materials, under Conditions of Changing Climate" (Ministry of Agriculture of the Czech Republic) and research project NAZV QJ1510179 "A comprehensive soil protection technology of planting Zea mays L. within the frame of crop production re-intensification".

\section{Appendix A. Supplementary data}

The summary of botanical composition and potential feed value of individual plant species in monitored permanent grassland. 


\section{References}

AвRHAm, Z: 2008: Technology and economy of solid biofuels from grassland. In. Biomass Use: Proceedings of Seminars 6. 11. 2008, Olomouc. Olomouc: Omnis, 7-15. (in Czech)

Carter, D.L., Blair, J.M. 2013: Seed source has variable effects on species, communities, and ecosystem properties in grassland restorations. Ecosphere, 4: 1-16.

CSU 2017: Statistical Yearbook of the Czech Republic 2017. Czech Statistical Office: Prague, $823 \mathrm{p}$.

da Silveira Pontes, L., Maire, V., Schellberg, J., LouAult, F. 2015: Grass strategies and grassland community responses to environmental drivers: a review. Agronomy for Sustainable Development, 35: 1297-1318.

Gaujour, E., Amiaud, B., Mignolet, C., PlantuREUX, S. 2012: Factors and processes affecting plant biodiversity in permanent grasslands. A review. Agronomy for Sustainable Development, 32: 133-160.

Givens, D.I., Owen E., Axford, R.F.E., Omed, H.M. (EDs.) 2000: Forage evaluation in ruminant nutrition. CABI Publishing, Wallingford, UK, $496 \mathrm{pp}$.

HANŽL, P., BuriânKovÁ, K. 2000: Moravikum. In. Müller, P., Novák, Z. Geology of Brno and surroundings. Praha: Czech Geological Survey,17-19. (in Czech)

Hejcman, M., Klaudisová, M., Schellberg, J., HonsovÁ, D. 2007: The Rengen Grassland Experiment: Plant species composition after 64 years of fertilizer application. Agriculture, Ecosystems and Environment, 122: 259-266.

Hejcman, M., Schellberg, J., Pavlơ, V. 2010: Longterm effects of cutting frequency and liming on soil chemical properties, biomass production and plant species composition of LolioCynosuretum grassland after the cessation of fertilizer application. Applied Vegetation Science,13: 257-269.

HejDuk, S. 2012: Red clover Plant which changed an European agriculture. Vesmír, 91(11): 642646. (in Czech)

HorkÝ, P., SKLÁdanKa, J., ŠEDA, J. 2013: Regeneration of grasslands and methods of studying grassland ecosystems. Brno: Mendelova univerzita v Brně, 56 pp. (in Czech)

Hrabě, F. 2003: Grass and lawns - what about them do not know. Vydavatelství Ing. Petr Baštan, Olomouc, 158 pp. (in Czech)
KLapp, E. 1956: Wiesen und Weiden. Behandlung, Verbesserung und Nutzung von Grünlandflächen. Parey, Berlin, 519 pp.

Kohoutek, A., Odstrěrllová, V., Nerušil, P., KomÁREK, P. 2007: Estabilishment permanent grasslands in LFA. Methodologies for agricultural practice. Crop Research Institute, Praha. 24 p. (in Czech)

KoníčEK, B. 1966: Inventarization and classification of grassland in the CSSR. MZVH Praha. 64 p. (in Czech)

Kubât, K., Hrouda, L, Chrtek, J. jun., Kaplan, Z., KirsChNeR, J., ŠTĚPÁNeK, J. [EDS.] 2002: Key to the Flora of the Czech Republic. Academia, Praha, 928 p. (In Czech)

Meloun, M., Militký J. 2011: Statistical Data Analysis, A Practical Guide with 1250 Exercises and Answer key on CD, Woodhead Publishing India, 1600.

Meloun, M., MilitкÝ, J. 2012: The interactive statistical analysis. 4. Edition, Karolinum Praha, 955 p. (in Czech)

Michaud, A., Plantureux, S., Amiaud, B., Carrère, P., Cruz, P., Duru, M., Dury, B., Farruggia, A., Fiorelli, J.L., Kerneis, E., Baumont, R. 2012: Identification of the environmental factors which drive the botanical and functional composition of permanent grasslands. The Journal of Agricultural Science, 150(2): 219-236.

MZE 2015: Situation prospective report: Soil. Ministry of Agriculture of the Czech Republic, Praha. 134 pp. ISBN 978-80-7434-252-3. (in Czech)

NěmeČek, J., Mackủ, J., Vokoun, J., VavŘ́ǐče, D., NovÁk, P. 2011: The taxonomic soil classification system in the Czech Republic, 2. Edition. Czech University of Life Sciences in Prague, 94. (in Czech)

Nerušil P., Komárek P., Menšík L. 2016: Plant species composition and potential feed value of permanent grasslands in the central part of Drahanská vrchovina Upland. Beskydy, 9 (1-2): 9-20.

Nerušil, P., Kohoutek, A., KomÁrek, P., OdstrČIlLOVÁ, V., NĚMcovÁ, P. 2012: Evolution of forage quality of selected grass species during the first harvest regrowth. In. GoLIŃski, P. et al. (eds.). Grassland - a European Resource? Proc. of the $24^{\text {th }}$ Gener. Meet. of the EGF, vol. 17, Lublin, Poland, 3-7 June 2012, 379-381. 
Nerušil, P., Menšík, L., Houdek, I., Jurka, M., StrašIL, Z., KoHoutek, A. 2016: Crop management, production and forage quality of selected grass varieties and grass mixtures as a maize substitute for biogas plants. Methodologies for agricultural practice. Crop Research Institute, Praha. 27 pp. (in Czech)

Novák, J. 2008: The pastures, meadows and lawns. Patria I., spol. s r. o. Prievidza, 708 pp. (in Slovak)

Pozdíšek, J., Kohoutek, A., BJelKa, M., NerušIL, P. 2004: Utilization of grassland by suckler cow rearing. Agricultural information, no. 2, UZPI, Praha. 103 pp.

RychnovsKá, M., Balátová-TuláčKovÁ, E., ÚleHLová, B. 1985: Ecology of grasslands. Praha: Academia, 291 pp. (in Czech)

StATSOFt ČR, s. r. o. 2014: STATISTICA.Cz, ver. 12. 0. www.statsoft.cz.

SteinWidder, A., Wurm, K. 2003: Weidemanagement für Milchkühe - Was kann und soll die Weide leisten? In: „Der Fortschrittliche Landwirt“, Heft 2/2003, 16 pp.

ŠTÝBnAROVÁ, M. 2011: Changes in species diversity and organic matter digestibility at different intensity grassland management. Dissertation thesis. CZU Praha. 147 pp. (in Czech)

WALdén, E, Lindborg, R. 2016: Long Term Positive Effect of Grassland Restoration on Plant Diversity - Success or Not? Plos One, 11: e0155836. https://doi.org/10.1371/journal. pone.0155836

WRB 2014: IUSS Working Group WRB. World Reference Base for Soil Resources 2014. International soil classification system for naming soils and creating legends for soil maps. World Soil Resources Reports No. 106. FAO, Rome. 


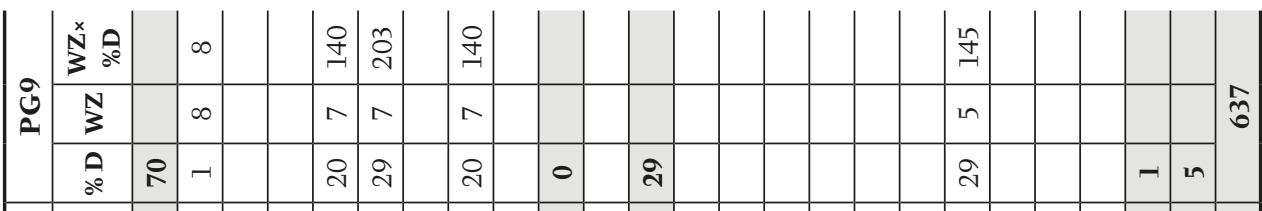

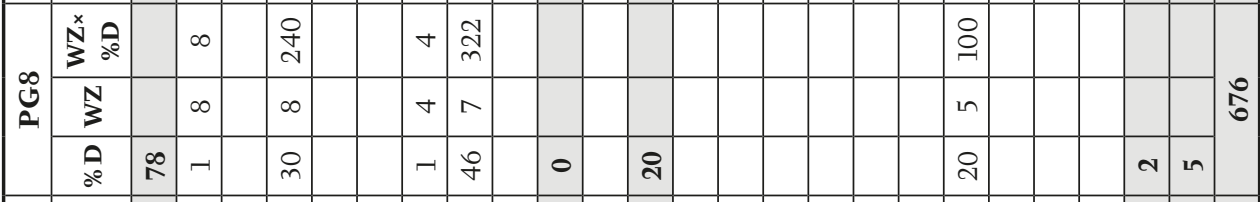

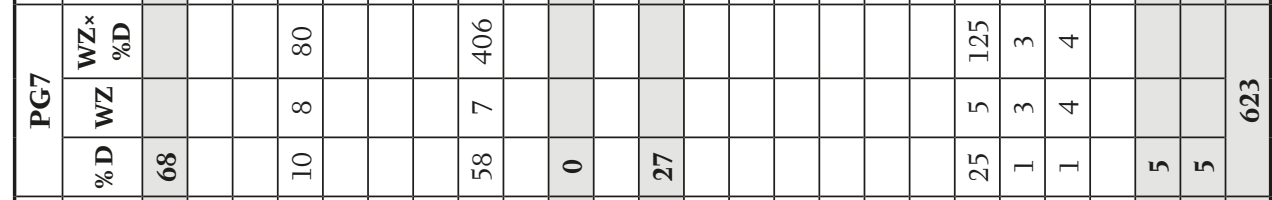

हैं

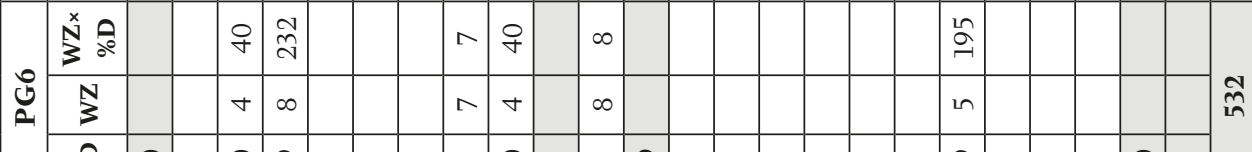

$\stackrel{\infty}{\stackrel{5}{\leftrightarrows}}$

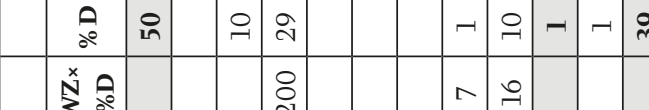

in

.

$\stackrel{2}{\circledR}$

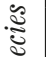

का

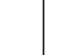

范

ㄴ.

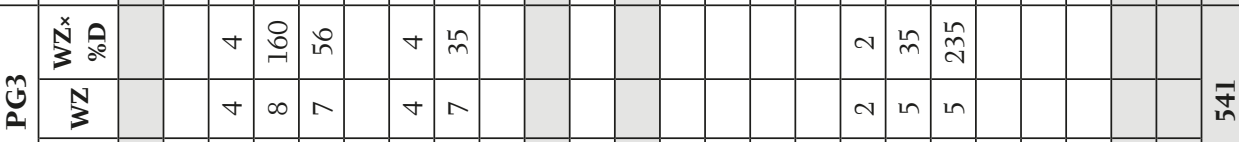

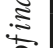

ڤ

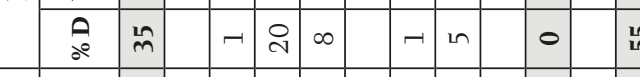

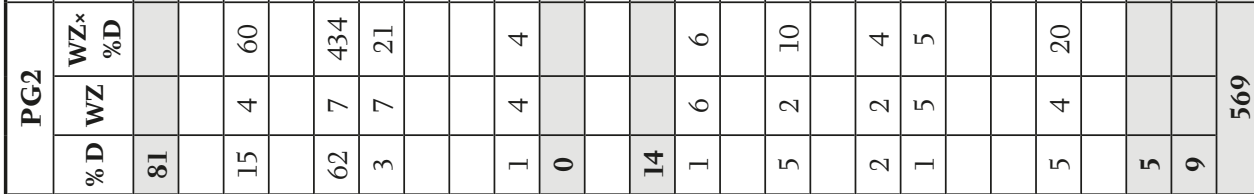

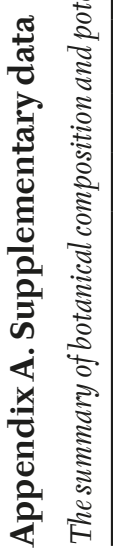

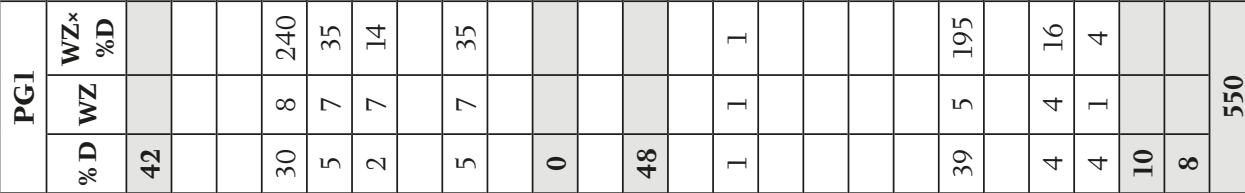



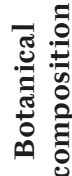

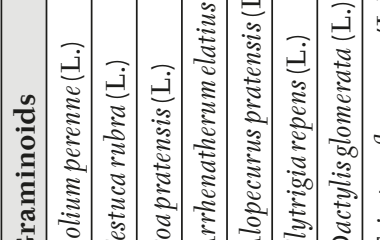

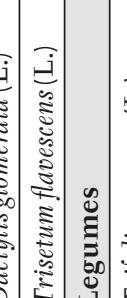

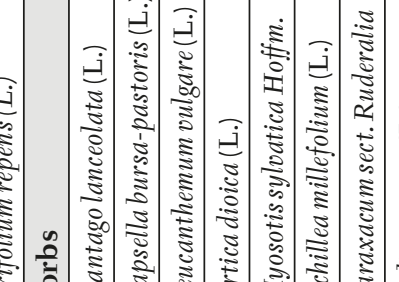

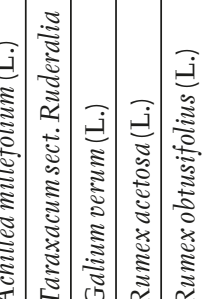

을

ติ

ริ +

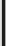

